\section{Win some, lose some}

There are times when things flow smoothly and times when they don't. ET has recently experienced both, relating to matters raised in Comment in ET61 (16:1, Jan 00), which celebrated fifteen years of publication.

In that issue, I sought to highlight the range of contributions published since we began in 1985. As part of this, I took points raised by Nigel Ross in his neatly titled 'Signs of International English' (ET50, Apr 97). In that article, he analysed Anglo-hybrid shop signs in Milan in Italy. For my response, I chose signs in Zurich in Switzerland and in Uppsala in Sweden, and called my piece 'Interanto: the global language of signs' (ET61, Jan 00). What I noted in Switzerland and Sweden paralleled what he had found in Italy.

Since then, ET has published a growing number of reports on signs and ads in various places, all focusing on both hybridity and the prominence and prestige of English. The present issue continues the trend, with Maria Schlick's second report, which not only extends her study of shop signs in towns in Austria, Italy, and Slovenia (in ET70, Apr 02), but takes on England as well. She is also noteworthy in having made the subject central to a project for a master's degree, now successfully completed.

But win some, lose some. In the same editorial (Jan 00), there was a sidebar with the title 'ETelectronic', referring to an e-forum we planned to start up, in which readers, contributors, and others could interact under the adjudication of editorial board member Alan S. Kaye of the University of California Fullerton. When, much later, the service went on-line, ETe had hundreds of hits but unfortunately nothing to hit on because of a dispiriting series of technical faults. When these were at length by and large cleared up, I wrote a piece on the language of what is now known simply as '9/11'. This was reproduced in ET69 (18:1, Jan 02), along with news about ETe, and accompanied by two early online responses. But by this time, unfortunately, both the momentum and the moment were lost, and the project did not thrive.

Cambridge University Press has therefore with great regret decided not to continue the service. But we do have in this issue our largest surveys to date of hybrid shop signs: from both Europe and Japan. Lose some, win some.

Tom McArthur

The editorial policy of English Today is to provide a focus or forum for all sorts of news and opinion from around the world. The points of view of individual writers are as a consequence their own, and do not reflect the opinion of the editorial board. In addition, wherever feasible, ET generally leaves unchanged the orthography (normally British or American) and the usage of individual contributors, although the editorial style of the journal itself is that of Cambridge University Press.

(c) Cambridge University Press 2003. No contents may be reproduced by any means without the permission of Cambridge University Press.

Print ISSN 0266-0784 Electronic ISSN 1474-0567

Publisher: Cambridge University Press, The Edinburgh Building, Cambridge CB2 2RU, United Kingdom. Telephone (01223) 326070 Email:

journals_marketing@cambridge.org

Subscriptions: The 2003 subscription price (excluding VAT) for four issues for libraries and institutions is $f 71$ for the electronic-only version and $f 79$ for the print plus electronic versions. The print-only version is available at $\mathrm{f} 32$ for individuals and $\mathrm{f24}$ for students and the retired. Prices include delivery by air where appropriate. Send your order to Customer Services at the above address.

Advertising Sales: write to the Advertising Promoter at the above address.

USA, CANADA AND MEXICO:

Publisher: Cambridge University Press, 40 West 20th Street, New York

NY 10011-4211, USA.

Telephone 19149379600.

Subscriptions: The 2003 subscription

price for four issues for libraries and

institutions is $\$ 108$ for the electronic-

only version and $\$ 124$ for the print

plus electronic versions. The print-only version is available at $\$ 50$ for

individuals and $\$ 37$ for students and

the retired. Apply to Marianne

Headrick at the above address.

Advertising Sales: write to the Advertising Coordinator at the above address.

Periodicals postage paid at New York, $\mathrm{NY}$ and at additional mailing offices. POSTMASTER: send address changes in

USA, Canada and Mexico to English Today, Cambridge University Press, 110 Midland Avenue, Port Chester, New York, NY 10573-4930, USA.

Japanese prices for institutions are available from Kinokuniya Company Ltd, P.O. Box 55, Chitose, Tokyo 156, Japan.

Letters to the Editor: write to Dr Tom McArthur, Editor, English Today, 22-23 Ventress Farm Court, Cherry Hinton Road, Cambridge CB1 8HD, UK. Tel 01223 245934, Fax 01223241161.

Email: Scotsway@aol.com

Internet access This journal is included in the Cambridge Journals Online service which can be found at http://journals.cambridge.org. For further information on other Press titles access http://uk.cambridge.org.

Designed and typeset by Peter Ducker Printed in the United Kingdom at the University Press, Cambridge.

DOI: $10.1017 / \mathrm{S} 0266078403001123$ 